\title{
Evaluation of Released and Local Groundnut Varieties against Groundnut Rust (Puccinia Arachidis) at Babile, Eastern Ethiopia
}

\author{
Mastewal $\mathrm{A}^{1 *}$, Sakhuja $\mathrm{PK}^{2}$ and Mashilla $\mathrm{D}^{2}$ \\ 1Department of Horticulture, Debre Markos University, Ethiopia \\ ${ }^{2}$ School of Plant Sciences, Haramaya University, Ethiopia
}

\section{Research Article}

Volume 2 Issue 1

Received Date: January 18, 2017

Published Date: February 01, 2017

*Corresponding authors: Mastewal Alehegn, Department of Horticulture, Debre

Markos University, Ethiopia, Tel: 0587716769; 0587711764; E-mail: mastewal.alehegn@gmail.com

\section{Abstract}

Groundnut is the most important oil crop in Hararghae, Eastern Ethiopia. Currently the production of the crop is threatened by a number of abiotic and biotic factors and leaf rust caused by Puccinia arachidis being one of the important biotic constraints in the area. Field experiments were carried out at Babile Research Sub-Station of Haramaya University in 2010 main cropping season to assess the reaction of seven released and two local groundnut varieties against rust. The experiment was laid out in a randomized complete block design (RCBD) with three replications for groundnut variety screening. The evaluated nine varieties varied significantly in disease severity, AUDPC, disease progress rate, yield and yield components. The tested varieties had varying reactions to the disease, on the basis of which four groups were identified, viz. resistant (one variety), moderately resistant (four varieties), moderately susceptible (two varieties) and susceptible (two varieties). The most resistant of all the varieties was Werer 962, which showed PSI of 36.41\%, AUDPC of $251.61 \%$-days, disease progress rate of 0.010 unit per day and rust scale of (2.68) value. This resistant variety (Werer 962) produced the highest yield of all the rest varieties. In the future, more extensive studies for assessment of varieties for specific regions and identification of control measures against groundnut rust would contribute to stabilizing groundnut production in eastern Ethiopia.

Keywords: Arachis hypogeal; AUDPC; Disease incidence; Groundnut; Percentage severity index; Puccinia arachidis

\section{Introduction}

Groundnut or peanut (Arachis hypogea L.) is an important oil seed crop, grown throughout the tropics between $40^{\circ}$ South and $40^{\circ}$ North of the equator where the annual rainfall ranges between 500 to $1200 \mathrm{~mm}$ and with average daily temperature of higher than $20^{\circ} \mathrm{C}$. The crop is grown in tropical and subtropical regions of the world. It is grown in six continents, but mainly in Asia,
Africa and America in over 100 countries with a world production of 37.10 million metric tons from an area of 23.11 million hectares [1]. Groundnut is one of the four economically important oilseed crops including noug, flax and sesame in Ethiopia and is largely produced in the eastern part of the country [2].

Groundnut plays an important role in the diets of rural populations, particularly children, because of its high 


\section{Open Access Journal of Agricultural Research}

contents of protein (21-30\%), fat (41-52\%), and carbohydrate (11-27\%). It is rich in calcium, potassium, phosphorus, magnesium, vitamin $\mathrm{E}$, vitamin $\mathrm{B}_{1}, \mathrm{~B}_{2}, \mathrm{~B}_{6}$, nicotinic acid and other vitamins. It is also a good source of lecithin present to the extent of 0.5 to $0.7 \%$ in decorticated nuts [3]. It is an important food source with a high protein and fat contents, some varieties containing greater than $50 \%$ edible oil [4]. In eastern Ethiopia mainly high quality edible oil is extracted from groundnut and cakes are made from the remaining residue. The shell is used for fuel and as organic fertilizer in many regions. Besides its superior food value, groundnut also provides a source of cash for resource-poor farmers. Groundnut earns foreign currency for the country over 2 million US dollar was obtained in 1989 [5]. With the current interest in export-oriented agriculture, the future groundnut market situation appears promising for Ethiopia.

Despite its importance, the average national yield (about $1.2 \mathrm{t} / \mathrm{ha}$ ) of groundnut in Ethiopia is significantly lower than is potentially achievable (over $2.0 \mathrm{t} / \mathrm{ha}$ ) [6]. This large gap between actual and potential yields is due to several factors, including non-availability of seeds of improved varieties, poor soil fertility, inappropriate crop management practices, and insect pests and diseases. Foliar fungal diseases such as the leaf rust occurs every year in many parts of eastern Ethiopia and cause yields reduction up to $65 \%$ especially in areas with high rainfall [6]. Rust Ethiopia and causes losses in yield of food insure farmers [7].

To reduce its prolific development and growth, of the disease there is a need for alternative plant disease management options that provide effective management of the disease under question while minimizing cost and negative consequences to human health and the environment. Thus, the use of resistant cultivars is widely recognized as the safest, most economical and most effective method for protecting crops from disease. Therefore, the study was designed to assess the reaction of released and local groundnut varieties against groundnut rust.

\section{Materials and Methods}

\section{Description of the Study Site}

The field experiment was conducted at Babile Sub Research Station of Haramaya University in East Hararghae Zone during 2010 main cropping season. The research station is located at longitude of $9^{\circ} 08^{\prime} 40^{\prime \prime}$ North, latitude $42^{\circ} 21^{\prime} 30^{\prime \prime}$ East at an altitude of $1650 \mathrm{~m}$ a.s.l. The area is characterized by bimodal rainfall pattern occurring mainly during March to May and July to October. The average rainfall is $671 \mathrm{~mm}$ per annum with a mean temperature of $22^{\circ} \mathrm{C}$. The averaged annual temperature data for Babile show a maximum and a minimum temperature of $28.05^{\circ} \mathrm{C}$ and $15.52^{\circ} \mathrm{C}$, respectively [8]. The type of soil at Babile Research Station is a well drained sandy-loam with $\mathrm{pH}$ 7.0, organic matter $1.9 \%$ and available phosphorus $3.2 \mathrm{ppm}$.

\section{Evaluation of Groundnut Varieties for Resistance to Rust}

Treatments, procedures and experimental design: A total of nine varieties (seven improved groundnut varieties, namely Werer 961, Sedi, Werer 962, Nc-4x, Shulamith, Roba and Nc-343, and two local varieties, namely Sartu and Oldhale varieties were evaluated (Table 1).

The treatments were arranged in randomized complete block design (RCBD) with three replications. The plot size was $5 \mathrm{~m} \mathrm{x} 2 \mathrm{~m}\left(10 \mathrm{~m}^{2}\right)$ and there were five rows per plot and five plants per row were taken from the central three rows and 15 plants per plot were tagged for data recording, Distance between plots was $60 \mathrm{~cm}$, while the distance between blocks was $1 \mathrm{~m}$ and row-to-row distance was $35 \mathrm{~cm}$ and plant-to-plant distance was 25 $\mathrm{cm}$. Planting was done on 30 April 2010 by dropping two seeds per hole and the less vigorous seedlings were thinned out afterwards. All recommended agronomic practices were done as required.

Rust Assessment: Disease incidence was recorded by counting the number of infected plants from the central three rows in proportion of the total plants and then, converted into percentage, while disease severity was recorded by estimating the percentage of leaf area diseased using the 1-9 disease scoring scale [9] on the 15 tagged plants in the middle three rows of each plot every seven days starting from the first appearance or onset of the disease symptoms. Disease severity scores were then converted into percentage severity index (PSI) for the analysis using the formula stated below.

$$
\text { PSI }=\frac{\text { SNR } \times 100}{\text { No.PS } \times \text { MSS }}
$$

Where SNR =Sum of numerical ratings, No.PS= number of plants scored and MSS= maximum score on scale.3.4. Data collected in the field. 


\section{Open Access Journal of Agricultural Research}

Disease incidence: This was assessed by counting the number of plants showing rust symptoms on the central three rows of every plot in proportion to the total plant in the row and then converted into percentage.

Disease severity: Percent tissue area affected by the disease was assessed on 15 tagged plants in the central three rows of every plot. Data were recorded using 1-9 disease scale [9]. Severity was expressed as PSI computed based on 1-9 disease scale.

Stand count at harvest: Number of plants in the central three rows at harvest was counted.

Number of pods per plant: Number of pods per plant was recorded from 15 tagged plants at harvest.

Number of seeds per pod: number of seeds per pod was recorded from 15 tagged plants from each plant 5 pods shelled to find out number of seeds.

Hundred seed weight measures: 100 seed weight were recorded by taking 100 seeds from each 15 tagged plants and expressed by gram.

Shelling percentage: This was calculated from 15 tagged plants by dividing the weight of seeds to the weight of pods and multiplying it by 100 .ss

Yield kg/ha: This was recorded from the harvested plots and converted into $\mathrm{kg} / \mathrm{ha}$.

Data Analysis: The percentage data on disease incidence and severity were subjected to ANOVA to determine the treatment effects. Mean disease severity from each plot was used in data analysis. Disease progress rate was obtained from the regression of PSI data fit to logistic model loge (y/1-y) [10] with dates of assessments. The area under disease progress curve (AUDPC) was calculated for each plot using the formula of [11] as follows.

$\mathrm{i}=1$

$$
A U D P C=\Sigma\left[\left(X_{i}+X_{i+1}\right) / 2\right]\left[t_{i+1}-t_{i}\right]
$$

Where $x_{i}$ is the cumulative disease severity expressed as a proportion at the $\mathrm{i}^{\text {th }}$ observation (percentage of disease severity) $t_{i}$ is time of the $i^{\text {th }}$ assessment in days from the first assessment date and $n$ is the total number of assessments made.

Correlation analysis was performed to determine the relationship between yield and AUDPC across the treatments. The relationships of AUDPC, severity, disease progress rate and yield were examined using correlation analysis. Least significant difference (LSD) value was used to separate the treatment means. Data were analyzed by using statistical analysis software version 9.0.

\section{Results and Discussion}

\section{Reaction of Groundnut Varieties to Rust}

Disease Incidence: Incidence of groundnut rust during initial assessment at flowering stage varied significantly ( $p \leq 0.001$ ) (Appendix Table 1) among the varieties. The highest initial incidence $(79.41 \%)$ was recorded on the variety Shulamith while it was the lowest $(54.85 \%)$ on the variety Werer 962 (Table 4). There were no significant (p $>0.05$ ) difference between Shulamith and Roba in terms of initial incidence. Shulamith had significant ( $p \leq 0.05$ ) difference from seven of the varieties in initial disease incidence with the exception of Roba. On the other hand, varieties Sedi and Oldhale had similar initial disease incidence (Table 1).

Rust incidence at final assessment (i.e. at the second scoring time) was also significantly $(\mathrm{p}<0.001)$ different among the varieties (Appendix Table 1). Relatively low final incidence was recorded on the varieties Werer 962 (61.80\%), Sartu (64.89\%) and Oldhale (65.36\%) (Table 2 ). The levels of final disease incidence on Shulamith and Roba were also significantly different from that of the other varieties tested these varieties showed consistent reaction at their initial and final disease incidence, in that both had significantly higher initial and final disease incidence. Groundnut rust appeared in all the varieties during the third assessment (92 DAP). To this effect, the data were not included in the statistical analysis since the incidence was $100 \%$ in all of the varieties. Differences in disease incidence among the varieties might result from partial resistance, which would reduce infection efficiency, uredium size and sporulation during each cycle of infection [12].

Rust development on groundnut varieties: Groundnut rust development was evaluated using disease severity, AUDPC, disease progress rate and rust scale. These parameters were finally used to classify reaction groups among the groundnut varieties evaluated. During the growing season differences between partially resistant and susceptible varieties might become greater, even though all varieties developed some resistance with increase in age (Table 2). 


\section{Open Access Journal of Agricultural Research}

Disease Severity: The mean disease severity score of the test varieties for rust disease ranged from 2.68 (resistant) to 7.88 (susceptible) (Table 2). The severity of rust on the groundnut varieties evaluated under natural infections using 1-9 disease scale [9] showed different levels of disease reaction (Figure 1). Very highly significant variations $(\mathrm{p}<0.001)$ were observed in severity of rust among the varieties (Appendix Table 2). Different levels of rust severities (as percent severity index) were recorded on the different varieties tested under natural infection. The varieties more or less showed differential responses to the rust. The mean percent severity index (PSI) ranged from $61.27 \%$ for Shulamith (susceptible) to $36.41 \%$ for Werer 962 under natural infection (Figure 1, Table 2). Compared to the susceptible variety the second highest mean percent severity (58.07\%) was recorded on the variety Roba (Figure 1, Table 2). This variety had a marked difference in severity from all the other varieties. On the other hand, levels of disease severity were notably low on the varieties Werer 962, Sartu and Old hale, which had $36.41 \%, 45.95 \%$ and $48.07 \%$, respectively. However, none of the varieties exhibited an immune reaction to the disease.

Varieties categorized under the same group were comparable in their responses to the disease parameters and rust reaction groups. The variety Werer 962 showed the lowest disease severity, relative to the other varieties, the level of severity on this variety was significantly different ( $p \leq 0.0001$ ) from that of all the other varieties (Appendix Table 2), whereas the varieties Werer 961 and Sedi were not significantly different in their mean disease severity, but the variety Nc-4x and Nc-343 had similar levels of disease reaction which were estimated at $(54.56 \%)$ and $(55.52 \%)$ mean disease severity, respectively (Table 1 ).

\begin{tabular}{|c|c|c|}
\hline Genotype & 78DAP & 85 DAP \\
\hline Werer 962 & $54.85^{\mathrm{e}}$ & $61.80^{\mathrm{h}}$ \\
\hline Werer 961 & $63.48^{\text {bcd }}$ & $75.81^{\mathrm{f}}$ \\
\hline Shulamith & $79.41^{\mathrm{a}}$ & $94.05^{\mathrm{b}}$ \\
\hline Sedi & $60.21^{\text {cde }}$ & $79.92^{\mathrm{e}}$ \\
\hline Nc-4x & $68.51^{\mathrm{b}}$ & $84.58^{\mathrm{c}}$ \\
\hline Roba & $77.11^{\mathrm{a}}$ & $88.14^{\mathrm{b}}$ \\
\hline Nc-343 & $65.61^{\mathrm{bc}}$ & $83.00^{\mathrm{d}}$ \\
\hline Sartu & $57.57^{\text {ed }}$ & $64.89 \mathrm{~g}$ \\
\hline Oldhale & $59.15^{\text {cde }}$ & $65.36^{\mathrm{g}}$ \\
\hline LSD $(0.05)$ & 7.18 & 1.33 \\
\hline CV $(\%)$ & 6.37 & 0.99 \\
\hline
\end{tabular}

Table 1: Mean levels of initial and final disease incidence of rust on the groundnut varieties evaluated at Babile in 2010 main cropping season.

Means with the same letter in the same column are not significantly different, DAP= days after planting.

The disease severities in the susceptible varieties were significantly higher than those on the other varieties in all assessment dates (Figure 1).

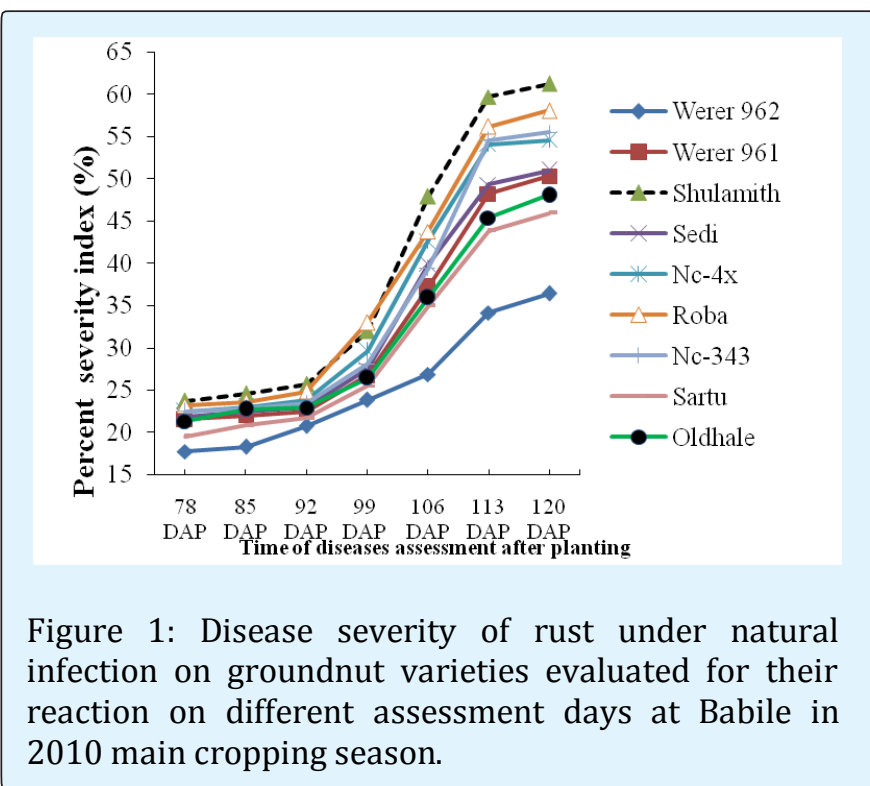

Consistent findings were reported by Bromfield and Cevario (1970). Differences in mean disease severity could be due to variation in the pathogen, could be responsible where interaction between host pathogen and environment or variation within the host species. Thus this work was consistent with the previous findings. In Ethiopia, there were no promising varieties screened against rust infection. This current investigation implies the need for further studies.

Area under disease progress curve (AUDPC): The area under disease progress curve (AUDPC) is a very convenient summary of plant disease epidemics that incorporates the initial intensity, the rate parameter and the duration of the epidemic which determines the final disease intensity [13]. Hence the effects of disease resistance on disease progress on crops can be evaluated using AUDPC Boiteux (1995) [14] also used AUDPC as a criterion for resistance by comparing AUDPC values of many genotypes with that of a resistant variety. Thus this study was used the following parameters for classifying the varieties into susceptible or resistant categories. The 


\section{Open Access Journal of Agricultural Research}

criteria tried were low AUDPC, low infection rate, low severity, and low rust scale value according to proposed cereal rusts and are defined by characteristic lesion types. The host responses resistant (rust scale 2-3), moderately resistant (rust scale 3-5), moderately susceptible (rust scale 5-7), and susceptible (rust scale 7-8) were detected in the present study [15].

Accordingly, the varieties were classified into either of $\mathrm{S}$ (susceptible), MS (Moderately susceptible), MR (moderately resistant) or resistant (R) reaction types. Among the nine groundnut varieties screened, Werer 962 was found to be resistant (R) because it had least severity, AUDPC, infection rate and rust scale. The four varieties scale of reaction types for the groundnut-rust pathosystems. The reaction classes are derived from for namely Sartu, Oldhale, Sedi and Werer 961 appeared to cluster together in their severity level, AUDPC, infection rate and rust scale even if the former two varieties and the latter two varieties had different values of disease parameters, which might be described as moderately resistant (MR). Likewise, Nc-4x and Nc-343 had similar severity levels AUDPC, rust scale and different infection rates and thus were grouped as moderately susceptible (MS). The disease parameter on Shulamith and Roba was markedly higher than the rest test varieties that were identified as susceptible varieties (Table 2).

\begin{tabular}{|c|c|c|c|c|c|}
\hline Groundnut Variety & Final PSI & AUDPC & DPR & Rust Scale & Rust Reaction \\
\hline Werer 962 & $36.41^{\mathrm{g}}$ & $251.61^{\mathrm{g}}$ & $0.010^{\mathrm{d}}$ & $2.68^{\mathrm{f}}$ & R \\
\hline Werer 961 & $50.32^{\mathrm{d}}$ & $345.56^{\mathrm{d}}$ & $0.018^{\mathrm{bc}}$ & $4.46^{\mathrm{c}}$ & MR \\
\hline Shulamith & $61.27^{\mathrm{a}}$ & $426.70^{\mathrm{a}}$ & $0.029^{\mathrm{a}}$ & $7.88^{\mathrm{a}}$ & S \\
\hline Sedi & $51.00^{\mathrm{d}}$ & $345.5^{\mathrm{d}}$ & $0.014^{\mathrm{cd}}$ & $4.60^{\mathrm{c}}$ & MR \\
\hline Nc-4x & $54.56^{\mathrm{c}}$ & $380.35^{\mathrm{c}}$ & $0.020^{\mathrm{b}}$ & $5.13^{\mathrm{b}}$ & $\mathrm{MS}$ \\
\hline Roba & $58.07^{\mathrm{b}}$ & $409.86^{\mathrm{b}}$ & $0.027^{\mathrm{a}}$ & $7.75^{\mathrm{a}}$ & $\mathrm{S}$ \\
\hline Nc-343 & $55.52^{\mathrm{c}}$ & $383.93^{\mathrm{c}}$ & $0.020^{\mathrm{b}}$ & $5.46^{\mathrm{b}}$ & MS \\
\hline Sartu & $45.95^{\mathrm{f}}$ & $315.93^{\mathrm{f}}$ & $0.016^{\mathrm{bc}}$ & $3.11^{\mathrm{e}}$ & MR \\
\hline Oldhale & $48.07^{\mathrm{e}}$ & $329.38^{\mathrm{e}}$ & $0.016^{\mathrm{bc}}$ & $3.86^{\mathrm{d}}$ & MR \\
\hline LSD (0.05) & 1.14 & 3.65 & 0.005 & 0.36 & \\
\hline CV (\%) & 1.02 & 0.59 & 15.11 & 4.24 & \\
\hline
\end{tabular}

Table 2: Level of mean disease severity index (PSI), AUDPC, disease progress rate, rust scale and reaction group of groundnut varieties to rust at Babile during 2010 main cropping season.

Means with the same letter on the same column are not significantly different, $\mathrm{R}=$ resistance, $\mathrm{MR}=$ moderately resistance, MS = moderately susceptible, S = Susceptible PSI= Percent Severity Index, AUDPC= Area under Disease Progress Curve, DPR= Disease Progress Rate.

Values for the area under disease progress curve also varied significantly among the varieties (Table 3).

\begin{tabular}{|c|c|c|c|c|c|c|}
\hline Groundnut Variety & YPH (kg/ha) & PPP & HSW(g) & SPP & SP (\%) & SCH \\
\hline Werer 962 & $1279.31^{\mathrm{a}}$ & $26.97^{\mathrm{a}}$ & $65.06^{\mathrm{a}}$ & $1.98^{\mathrm{ab}}$ & $75.25^{\mathrm{a}}$ & $45.33^{\mathrm{a}}$ \\
\hline Werer 961 & $1024.45^{\mathrm{b}}$ & $20.37^{\mathrm{bc}}$ & $56.90^{\mathrm{c}}$ & $1.93^{\mathrm{bc}}$ & $67.22^{\mathrm{bc}}$ & $32.00^{\mathrm{d}}$ \\
\hline Shulamith & $958.63^{\mathrm{c}}$ & $14.66^{\mathrm{de}}$ & $48.56^{\mathrm{f}}$ & $1.78^{\mathrm{d}}$ & $56.52^{\mathrm{e}}$ & $27.33^{\mathrm{f}}$ \\
\hline Sedi & $740.38^{\mathrm{c}}$ & $12.57^{\mathrm{e}}$ & $51.20^{\mathrm{e}}$ & $2.01^{\mathrm{a}}$ & $63.66^{\mathrm{cd}}$ & $38.66^{\mathrm{c}}$ \\
\hline Nc-4x & $1053.30^{\mathrm{b}}$ & $19.79^{\mathrm{bc}}$ & $56.76^{\mathrm{c}}$ & $1.90^{\mathrm{c}}$ & $72.12^{\mathrm{ab}}$ & $30.00^{\mathrm{de}}$ \\
\hline Roba & $1071.03^{\mathrm{b}}$ & $17.15^{\mathrm{cd}}$ & $64.50^{\mathrm{a}}$ & $1.80^{\mathrm{d}}$ & $61.63^{\mathrm{d}}$ & $29.33^{\text {ef }}$ \\
\hline Nc-343 & $1078.09^{\mathrm{b}}$ & $17.26^{\mathrm{cd}}$ & $53.16^{\mathrm{d}}$ & $1.82^{\mathrm{d}}$ & $67.69^{\mathrm{bc}}$ & $29.33^{\text {ef }}$ \\
\hline Sartu & $1246.85^{\mathrm{a}}$ & $32.03^{\mathrm{b}}$ & $58.86^{\mathrm{b}}$ & $1.90^{\mathrm{c}}$ & $74.00^{\mathrm{a}}$ & $41.00^{\mathrm{b}}$ \\
\hline Oldhale & $1223.47^{\mathrm{a}}$ & $12.46^{\mathrm{e}}$ & $59.40^{\mathrm{b}}$ & $1.96^{\mathrm{ab}}$ & $73.11^{\mathrm{a}}$ & $30.33^{\mathrm{de}}$ \\
\hline LSD (0.05) & 60.78 & 3.56 & 1.82 & 0.05 & 5.11 & 2.29 \\
\hline CV (\%) & 3.26 & 11.26 & 1.84 & 1.77 & 4.34 & 3.93 \\
\hline
\end{tabular}

Table 3: Mean level of yield per hectare, pods per plant, hundred seed weight, seed number per pod, shelling percentage and stand count at harvest of groundnut varieties at Babile during 2010 main cropping season. 


\section{Open Access Journal of Agricultural Research}

Means within column followed by the same letter are not significantly different, PPP = Pod per Plant, YPH $(\mathrm{Kg} / \mathrm{ha})=$ Yield per Hectare, HSW $=$ Hundred Seed Weight, SPP $=$ Seed Per Pod, SP $=$ Shelling Percentage and SCH $=$ Stand Count at Harvest.

The highest AUDPC (426.70\% -days) was estimated on the variety Shulamith and the second highest AUDPC (409.86\%-days) was obtained from the variety Roba, whereas the lowest AUDPC (251.61\%-days) was calculated on the variety Werer 962 (Table 2). There were significant differences among varieties Shulamith, Roba and Werer 962 in AUDPC value. However, AUDPC-value for Sedi was not significantly different from that of Werer 961 and in the same way AUDPC-value for Nc- $4 \mathrm{x}$ was not significantly different from that of Nc-343 (Table 2). According to the previous finding AUDPC is directly related to the yield loss (Singh, 1989). This implies that, selection of varieties having lower AUDPC is acceptable for practical purposes.

Disease progress curve also provides critical information for designing all effective disease management system. In studies of components of resistance to groundnut rust, it was found that neither the size nor the frequency of stomata was correlated with resistance. But it was investigated that Uredospores germinated on leaf surfaces and the fungus entered through stomata irrespective of whether a genotype was immune, resistant or susceptible to rust. However, in immune varieties the fungus died shortly after entering the sub-stomata cavity [12].

Disease progress rate: The analysis disease progress rates were significantly $(\mathrm{p} \leq 0.001)$ different among the varieties. The maximum AUDPC was observed on Shulamith in the same way, relatively faster mean disease progress rate (0.029 unit per day) over the season was also observed on this variety. The second maximum AUDPC was observed on Roba and, faster mean disease progress rate ( 0.027 unit per day) over the season was seen on this variety (Table 3 ).

However, the disease progress rate of variety Shulamith were not significantly different from that of Roba (Table 3), On the other hand, variety Werer 961 was not significantly different from that of varieties Sartu and Oldhale in their disease progress rates (Table 3). The lowest disease progress rate per day after the onset of the disease was observed on the variety Werer 962 which mainly due to the lower amount of initial inoculum available for disease progress rate and the genetic makeup of the variety.

Effect of rust on groundnut varieties, yield and yield components: Groundnut varieties showed significant ( $p$ $\leq 0.001$ ) difference in their seed yield (Appendix Table 4).The highest seed yield $(1279.31 \mathrm{~kg} / \mathrm{ha})$ was obtained from the variety Werer 962, whereas the lowest $(740.38$ $\mathrm{kg} / \mathrm{ha}$ ) was obtained from Sedi. However, the yield obtained from the variety Werer 962 was not significantly different from that of Sartu and Oldhale. Similarly, yield of Werer 961 was not significantly different from that of Nc4x, Roba and Nc-343 (Table 4).

\begin{tabular}{|c|c|c|c|c|}
\hline & YPH(kg/ha) & PSI & AUDPC & DPR \\
\hline YPH(kg/ha) & ------- & & & \\
\hline PSI & $-0.83^{* *}$ & -------- & & \\
\hline AUDPC & $-0.85^{* *}$ & $0.94^{* * *}$ & $----\cdot--$ & \\
\hline DPR & $-0.68^{*}$ & $0.84^{* * *}$ & $0.85^{* * *}$ & -------- \\
\hline
\end{tabular}

Table 4: Correlation coefficients ( $\mathrm{r}$ ) between yield and rust disease parameters of groundnut varieties evaluated for reaction to groundnut rust under natural infection at Babile during 2010 cropping season.

$*$ = significant $(\mathrm{p} \leq 0.05), * *=$ highly significant $(\mathrm{p} \leq 0.01)$, ${ }^{* * *}=$ very highly significant $(\mathrm{p} \leq 0.001), \mathrm{YPH}=$ yield per hectare, PSI $=$ Percent Severity Index, AUDPC $=$ Area under Disease Progress Curve and DPR $=$ Disease Progress Rate.

Russell (1965) observed that rust reduced yield and percent yield reductions in the varieties and severity levels were directly proportional, but all varieties do not yield the same in the absence of disease(s).

Moreover, there were significant $(\mathrm{p}<0.001)$ differences among varieties in the number of seeds per pod, pods per plant, hundred seed weights, shelling percentage and stand count at harvest (Appendix Table 4). The highest hundred seed weight (65.06 g) was obtained from Werer 962, whereas the lowest (51.20 g) was obtained from Sedi. Despite the overall variation, no significant difference was detected in hundred seed weights between the two varieties Werer 962 and Roba (Table 6). Hundred seed weights obtained from Werer 961 and Nc-4x were $56.90 \mathrm{~g}$ and $56.76 \mathrm{~g}$, respectively. Furthermore, variety Sartu and Oldhale were not significantly different in terms of their hundred seed weight (Table 6). The two groundnut varieties, Werer 962 and Sedi, gave the highest pod number per plant and seeds per pod, respectively (Table 4). On the other hand, 


\section{Open Access Journal of Agricultural Research}

Oldhale (12.46) and Sedi (12.57) gave the lowest pod number per plant (Table 6). There were significant difference $(p<0.001)$ (Appendix Table 4) among varieties in response to stand counts at harvest. This might be due to reaction level of varieties to the rust disease. Generally, the reason why relatively highest seed yield was obtained from a given variety could not be only due to the resistance of the disease, but also due to some important genotypic characteristics of the particular variety.

Association of yield and disease parameters: The association of yield and disease parameters that included percent severity index (PSI), AUDPC and disease progress rate was evaluated using correlation analysis. The results revealed that yield and percent severity index of groundnut rust were significantly and negatively correlated $(\mathrm{r}=-0.83)$ (Table 5). This correlation indicates that the impact of rust severity on the yield of the groundnut varieties was high. Yield and AUDPC were also significantly and negatively correlated at a slightly higher level $(r=-0.85)$ than that of yield and percent severity index indicating that lower AUDPC implies higher yield. There was also slightly lower negative $(r=-0.68)$ correlation between yield and disease progress rate (Table 4).

A very strong significantly positive( $\mathrm{r}=0.94)$ correlation was observed between percent severity index of groundnut rust on groundnut varieties and AUDPC which indicated that varieties which were severely infected showed high AUDPC values. Similarly high positive correlation was observed between percent severity index and disease progress rate $(r=0.84)$. There was also a positive $(r=0.85)$ correlation between AUDPC and disease progress rate (Table 5). This is good evidence that the use of AUDPC as a criterion to classify the varieties into reaction groups is justifiable.

\section{Summary and Conclusions}

Groundnut is one of the four economically important cultivated oilseed crops, including noug, flax and sesame in Ethiopia. It is largely produced in the eastern part of the country. Groundnut yields are, however, reduced due to many abiotic and biotic factors of which leaf diseases mainly (leaf spot and rust) are economically important problems. Leaf rust of groundnut, which is caused by Puccinia arachidis, is the most common and economically important foliar disease of the crop. However, yet in Ethiopia no more research efforts have been directed to develop suitable methods for its management and to find out sources of resistance to the disease.
Nine groundnut varieties were evaluated, in a randomized complete block design (RCBD) with three replications, for their reaction to leaf rust under natural infection. The varieties showed varying levels of reaction to the disease. Significant variation was also observed in yield and yield components among the varieties. The criteria used for varietal evaluation were low AUDPC, infection rate, percent severity and rust scale value. Accordingly the varieties were classified into susceptible (S), moderately susceptible (MS), moderately resistant (MR) or resistant (R) reaction groups. The most resistant (R) of all the varieties was Werer 962, which obtained PSI (36.41\%), AUDPC (251.61\%-days), disease progress rate (0.33 unit per day) and rust scale value (2.68). The susceptible variety Shulamith had PSI (61.23\%), AUDPC (426.70\% -days), disease progress rate $(0.96$ unit per day) and rust scale value (7.88). The highest percent severity (58.07\%) other than the Shulamith was recorded on Roba variety which was also significantly different from the other test varieties. The highest disease progress rate $(0.96$ unit per day), was observed in the variety Shulamith, while the least (0.33 unit per day) was recorded on the variety Werer 962. Varieties Werer 961, Sartu, Oldhale and Sedi were categorized as moderately resistant (MR), while varieties $\mathrm{Nc}-4 \mathrm{x}$ and $\mathrm{Nc}-343$ were classified under moderately susceptible (MS) category based on their reaction to the disease. However, the disease progress rate did not prove to serve as a better parameter in classifying the varieties into resistance or susceptible reaction groups.

The variety Werer 962 appeared to have better resistance to groundnut rust and is a promising variety. Whether or not this variety has a real genotypic resistance remains to be investigated further. This variety can be used in combination with other control measures wherever the disease is a pervasive and pressing problem. To cut down yield losses due to diseases, breeders have developed improved resistant groundnut varieties. The improved groundnut varieties, coupled with integrated disease management, could raise farmers' net returns. It is generally believed that rust will not survive for long in groundnut trash; therefore eradication of volunteer groundnut plants during the fallow period is important in reducing primary inoculum sources.

Based on the findings of this study, it can be concluded that groundnut rust is an important disease that calls for due attention in the study area for effective and efficient management with fungicides and resistant varieties. Varietal selection is a major disease management decision as well because it dictates the potential for rust to reach 


\section{Open Access Journal of Agricultural Research}

various levels of severity under favorable infection. Further studies should be conducted to evaluate more groundnut varieties and to workout effective and economical management options for the rust diseases under different ecological infection and thereby to enhance high quality groundnut production in Ethiopia.

\section{References}

1. FAO (Food and Agricultural Organization) (2007) Food and Agricultural Organization of the United Nation, FAO Statistical Database.

2. Getnet A, Nigussie A (1992) Production and research on oilseeds in Ethiopia. In: Proceedings of the First National Oilseeds Workshop in Ethiopia, 3-5 December 1991. Addis Ababa: Institute of Agricultural Research. p 312.

3. FAO (Food and Agricultural Organization) (2004) Worldwide regulation for mycotoxins in food and feed in 2003.

4. Adugna W (1992a) Groundnut breeding in Ethiopia. In: Oil Seeds Research and Development in Ethiopia, Proceeding of the First National Oilseeds Workshop: 3-5, IAR Addis Ababa, Ethiopia. pp. 51-56.

5. Adugna W (1992b) Performance of elite groundnut varieties in Ethiopia. In: $\mathrm{R}$ Cnages Wara Rao and Subrahmanyam, Proceeding of the Fifth Regional Groundnut Workshop for Southern Africa, 9-12, Lilongwe, Malawi and Nicargua pp. 21-24.

6. Geremew, T, Asfaw T (1992) Groundnut and sesame diseases in Ethiopia. In: Proceedings of the First National Oilseeds Workshop in Ethiopia. Institute of Agricultural Research. Addis Ababa, Ethiopia. pp 312.

7. Getenet T, Sakhuja PK, Swart WJ, Tana T (2007) Integrated management of groundnut root rot using seed quality and fungicide seed treatments. Int J Pest Management 53: 53-57.
8. Abdi A (2004) The effect of plant density and variety on yield and yield components of groundnut at Babile, Eastern Ethiopia, Msc thesis Alemaya University, Alemaya: Ethiopia. pp 58.

9. Subrahmanyam P, McDonald D, Walliyer F, Reddy LJ, Nigam SN, et al. (1995) Screening methods and sources of resistance to rust and leaf spot of groundnut. Information Bulletin No. 47, Patancheru. 502324, Andhra Pradesh, India, ICRISAT p 24.

10. Van der Plank JE (1963) Plant disease epidemics and control. Academic Press, New York, pp 344.

11. Shanner G, Finney R (1977) Inheritance of slow mildewing resistance in wheat. In: Proceedings of American Phytopathology Society. pp 49-52.

12. Subrahmanyam P, Gibbons RW, Nigam SN, Rao VR (1980) Screening methods and further sources of resistance to peanut rust. Peanut Science 7(1): 253256.

13. Madden LV, Hughes G, Vandenbosch F (2008) The study of plant disease epidemics. The American Phytopathological Society, St. Paul, Minnesota, USA.

14. Boiteux LS, Reifschneider FJB, Fonseca MEN, Buso JA (1995) Research for early blight field resistance not associated with vegetative late maturity in tetraploid potato germplasms. Euphytica 83: 63-70.

15. Macneal FH, Konzak CF, Smith EP, Tate WS, Russell TS (1971) A uniform system for recording and processing cereal research data. p 42. USDA, Agric Res Serv Washington DCARS.

16. Campbell CL (1998) Disease progress in time. Modelling and data analysis. In: Jones DG (Ed.) The Epidemiology of Plant Diseases. Kluwer Academic Publishers Dordrecht. The Netherlands. pp 181-204. 